Saudi Journal of Humanities and Social Sciences

Abbreviated Key Title: Saudi J Humanities Soc Sci

ISSN 2415-6256 (Print) | ISSN 2415-6248 (Online)

Scholars Middle East Publishers, Dubai, United Arab Emirate

Journal homepage: http://scholarsmepub.com/sjhss/

Original Research Article

\title{
Juridical Analysis of Law Protection of Industrial Design Owners in the Trade Sector in Indonesia
}

\author{
Dr. Elpina, SH, $\mathrm{MH}^{*}$ \\ Rosita Nainggolan SH.MH Law Faculty of Simalungun University Indonesia
}

DOI: $10.36348 /$ SJHSS.2019.v04i10.006

| Received: 08.10.2019 | Accepted: 21.10.2019 | Published: 30.10.2019

*Corresponding author: Dr. Elpina

\section{Abstract}

The progress of the trade sector is related to the economic field so rapidly. It is accompanied by the development of science and technology, therefore the development of the economy will be more focused on the industrial sector. For this reason, Indonesia, which is one of the countries involved in world trade, needs to address industrial progress, especially related to the Industrial Design that is owned to provide legal protection against the Innovations (Novelty) produced. The method in this research is a normative/doctrinal study. The approach taken is through a legislative approach using materials as research sources that will be sought to be processed and subsequently will be analyzed to find answers of problem discussed. Based on the Research Results it could be stated that the registration Criteria of Industrial Design was to be registered with the new element criteria and as the first registers of the Industrial include a novelty element which must not be the same as the Industrial Design that has been disclosed previous. The right of industrial design legal protection would be coming up where there was an industrial design registration by the designer or owner of the design right, legal protection granted to the industrial design right is granted for a period of 10 years from the date of receipt (application) and cannot be extended again.

Keywords: Industrial Design, Novelty, Registration.

Copyright @ 2019: This is an open-access article distributed under the terms of the Creative Commons Attribution license which permits unrestricted use, distribution, and reproduction in any medium for non-commercial use (NonCommercial, or CC-BY-NC) provided the original author and source are credited.

\section{INTRODUCTION}

Along with advances in the trade sector which are closely related to the economic sector, and so the rapid competition that occurs in the Industry 4.0 phase, therefore the development of the economy will be more focused on the industrial sector. Indonesia, which is one of the countries participating in trade the world, it is necessary to advance the industrial sector owned to encourage competitiveness.

One way that can be taken to improve competitiveness related to the industrial sector is to take advantage of the role of Industrial Design'. Industrial Design is entitled to receive protection must have" Novelty "[1].

Which is one part of Intellectual Property Rights. Industrial Design plays a role for success of industry and trade in Indonesia. Industrial Design has Exclusive Rights. One of the functions it gives Exclusive Rights is to foster and implement a clean free trade system as well as honest competition and healthy so that the interests of the wider community can be protected from fraudulent acts carried out by parties with bad intentions. Without registration there will be no limit to the design of the industry, and also there will be no legal protection.

Industrial Design is a part of Intellectual Property Rights that has an exclusive character. Protection of industrial design is based on the concept of thinking that the birth of industrial design cannot be separated from the ability of creative creativity, taste, and intention possessed by humans. .In the Industrial Design, which is given an exclusive right by the state to the designer or design that he created for a certain period of time to be implemented alone, but who has the Industrial Design, can also give approval to other parties to implement it [2].

According to OK.Saidin Industrial Design is a part of Intellectual Property Rights. Protection of Industrial Design is based on the concept of thinking that the birth of Industrial Design is inseparable from the ability of creative creativity, race and initiative owned by humans, and is a product of human intellectuals, the product of civilization humans [3]. 
In this development phase, Intellectual Property Rights relating to Industrial Design experiences have various problems or disputes. The phenomenon of deviant violations under the case of Industrial Design will always occur; this is related to violations of Industrial Design Rights by using or registering the same design as the design belongs to others, and based on of this case, that kind of action was categorized as an act of cheating or violating the law. In fact, the motivation and the indication of the person who violated the Industrial Design was primarily for profit.

Article 38 of Law Number 31 Year 2000 concerning of Industrial Design, it is about Industrial Design to enable parties who feel an interest to sue over Industrial Designs that have been registered. Towards the new Industrial Design. The cause of the lawsuit was generally related to the Novelty requirements referred to in Article 2. Based on this Article, the Industrial Design right was given to the new Industrial Design.

The new Industrial Design if on the date of receipt, the industrial design was not the same as the existing disclosure. The disclosure can be seen from print or electronic media, including participating in exhibitions.

In practice, the novelty factor was not the case, this is evident from the cases that were processed in the State Court in Indonesia relating to Industrial Design which always led to the Supreme Court in 2014 out of 769 Special Civil Cases 44 cases of IPR (5.72\%) and most of them were cases related to Trademarks. In some of the Industrial Design cases, the focus of the debate generally ranges from the Elements of Novelty. The problems that arise in the context of this Industrial Design are primarily for profit.

\section{RESEARCH METHODS}

In this study used the Normative Juridical Approach Research Method namely: To find out how the law that applies to an existing legal problem [4]. Normative Juridical Approach was done by examining the materials of the Legal Literature related to the Issues discussed.

This research was Analytical Descriptive, which characterizes the overall condition of the object of research, analytical nature was the activity of grouping, categorizing in accordance with the objectives of this study to answer the problem of Legal Protection of Industrial Design in Indonesia [5].

Data analysis was carried out qualitatively as follows: Analysis carried out using no numbers and statistical formula, which was carried out with a case study of the problem discussed.

\section{Formulation of the problem}

- What are the novelty elements that must be fulfilled in the registration of the right to industrial design in the trade sector in Indonesia?

- How is the Application of Legal Protection against Industrial Design in the Trade Sector in Indonesia?

\section{DISCUSSION}

Novelty element that must be fulfilled in the Registration of Right to Industrial Design in the Trade Sector in Indonesia.

As it is known that the business world will always move dynamically, where businesses will always look for new breakthroughs in developing the business. This is increasingly rolling in the era of Industry 4.0 where expansion of the business world has penetrated the boundaries of space, time and territory of countries, especially in Indonesia. One of the breakthroughs made by these business actors is the development of businesses through the Franchise system in Indonesia and it is well known as a franchise. By using this kind of trade system, entrepreneurs meant to develop their businesses which were considered effective and appropriate in developing a company without requiring direct investment that involved cooperation from another parties. With the emergence of this business type would bring a logical consequence to the world of law, so that it would need adequate legal institutions to regulate the business.

The development of the design at the beginning around the 18th Century focused on the value of art and Aesthetic value rather than the Commercial Value and Useful Value, the method used was method of handicraft and art by collaborating with the traditional method. In line with the increasingly sophisticated development of Science and Technology along with the occurrence of the Industrial Revolution that occurred in the 19th Century was born a number of new industries that apply the process of production mechanisms to produce various new products.

In the 20th Century the development of Industrial Design was very rapid, especially in the field of Textile and Craft. With the rapid development of Technology, Science and inventions (innovation) supported these entrepreneurs could offer the excess capabilities possessed by the company to other parties in running the business, so that consumers can know the products produced or sold by him widely, so that the purpose of developing his business can be realized there are forms of license that are known today that are comprehensive [6].

Ok Saidin said that the Industrial Design is a part of Intellectual Property Rights. Protection of Industrial Design is inseparable from the ability of creativity, creation, taste and work owned by humans, which are the products of human civilization. Maulana 
stated that in compiling the Industrial Design System there are two approaches, namely: Patent Approach and Copyright Approach.

The Patent Approach is: Industrial Design that has the right to obtain protection must have novelty. Where the right of Industrial Design is granted by the State after going through the inspection process. While the Copyright Approach is that Industrial Design must have originality and the industrial design right which is held by the designer or holders of industrial design rights without going through a Substantive inspection process or merely applying formality checks.

\section{Industrial Designs According to Law Number 31 year of 2000 are}

"A creation of a shape, configuration, or composition of lines or colors, or a combination in the form of three dimensions or two dimensions that gives an aesthetic impression and can be realized in threedimensional or two-dimensional patterns and can be used to produce a product, goods, industrial commodities or handicraft "[7].

Based on the matters stated above, what is said of an Industrial Design in the criteria for registration which has the criteria for novelty and who registers than the Industrial Design for the first time and the registered Industrial Design has a novelty element which must not be the same as Industrial Design previously stated [8].

The Application of Legal Protection against Industrial Design in the Trade Sector in Indonesia. Legal protection is an illustration of the operation of a legal function to obtain the legal objectives. Protection and Law Enforcement is very important to do, because it can reach some achievements, namely:

\section{The Rule Establishment of Law Supremacy}

The rule of law means that law has absolute power in regulating the association of people in various kinds of life. In other words all of the actions of citizens and governments are always based on applicable law. The rule of law will not be achieved if the applicable rules are not established both by the community and law enforcement apparatures.

\section{The Justice Enforcement}

The main purpose of the law is to achieve justice for every citizen. Every citizen can enjoy his rights and carry out his obligations which are a form of justice. This can be obtained if the rules are enforced.

\section{To achieve Peace in the Community Life}

A life colored by a peaceful atmosphere is everyone's hope. Peace will be obtained if everyone feels protected in all aspects of life. That will be come true if the applicable rules are implemented [9]. In Industrial Design, there are several rights including:
Priority Rights, Exclusive Rights and Industrial Design Rights.

Related to the right of industrial design includes the exercise of the rights owned by itself and prohibits others without the consent of him as the owner to make, use, import, export and / or distribute the goods which are given the right of industrial design. However, there are exceptions, namely the exceptions in the use of industrial design rights for research and education purposes to the extent that they do not prejudice the reasonable interests of those industrial design rights holders.

In matters relating to the scope of the Industrial Design given protection /be protected is a new Industrial Design and it is not against to the applicable laws, public order, religion and decency [10].

Referring to Article 10 of Law Number 31 year of 2000 concerning Industrial Designs that is given on the basis of an application, where each application can only be used for one industry or for several industrial designs which constitute an industrial design unit or which have the same elements [11].

The legal protection of industrial design rights is legal protection arising where there is an industrial design registration by the designer or owner of the design right, where the legal protection of the industrial design rights will be given for a period of 10 years from the date of receipt (application) and not can be extended.

\section{CONCLUSION}

An Industrial Design in the criteria to be registered that has a new element of the criteria and who registered the Industrial Design for the first time and the Industrial Design to be registered must have a novelty element that must not be the same as the Industrial Design that was registered previously.

Legal protection granted to industrial design rights is legal protection arising in which there is a registration of industrial design by the designer or owner of the design right, where legal protection of the industrial design right will be granted for a period of 10 years from the date of receipt (application ) and cannot be extended anymore.

\section{REFERENCES}

1. httpps://m.hukumonline.com.Diakses Pada Tanggal 26 September 2019

2. Suripto. (2007). Kriteria Kebaruan Dalam Desain Industri, Univ. Idslam Indonesia Yogyakarta.

3. OK. Saidin, Asfek Hukum Kekayaan Intelektual, Rajawali Pers,

4. Munir F. (2018). Metode Riset Hukum Pendekatan Teori Dan Konsep, Rajawali Pers,2018 
5. Yuliasih. (2015). Perlindungan Hukum Desain Industri Dalam Pelaksanaan Prinsip Keadilan Menurut Teori Keadilan John Rawls (Studi Kasus Putusan Nomor 35 PK/PDT-SUS -HKI/2014) Jurnal Notarius Edisi 08 Nomor 2 September.

6. Gunawan Widjaya,Waralaba, Rajawali Pers, 2001

7. Penilaian Kebaruan Menurut Hukum Desain IndustriIndonesia. (2008). Hukum Online, 6.Nov 2008.

8. Budi Santoso, Kebaruan (novelty) Dalam Perlindungan Hukum Pemegang Hak Desain Industri Dari Tindakan Similiaritas Di Indonesia. https//www.nelti.com,publication.
9. Irwan Darwis, Penegakan Hukum Dan Perlindungan

Hukum.www.irwankaimoto.blogspot.com

10. Adiyan, A. K. (2013). Penerapan prinsip kebaruan (novelty) dalam perlindungan desain industri di indonesia (Studi Kasus Desain Industri Iphone 3G Apple Inc. v. Galaxy S Samsung Electronics Co. Ltd). Kumpulan Jurnal Mahasiswa Fakultas Hukum, 1(3).

11. Pasal 10 Undang-Undang Republik Indonesia No.31 Tahun 2000 Tentang Desain Industri. 